\title{
VERDENSLITTERATUR SET FRA HELIKOPTERHØJDE
}

\section{ANMELDELSE AF}

Svend Erik Larsen: Tekster uden gronser. Litteratur og globalisering, Århus, 2007 (Aarhus Universitetsforlag)

Skal vi nu til at elske globaliseringen? Nej, det er ikke akkurat det, der er budskabet i Svend Erik Larsens bog Tekster uden granser, som er et stort essay på 13 kapitler med lige så mange vinkler på emnet litteratur og globalisering. Men vi kan ikke sidde globaliseringen overhørig, og frem for at frygte den skal vi meget hellere komme på niveau med den og møde dens vilkår som en chance for at udvide vores egen viden og erkendelse af, hvad det er, der er på færde. Frem for alt er budskabet fra litteraturprofessoren, at vi skal lase globaliseringen. Vi skal bruge litteraturen til at forstå den, og vi skal læse om den i den fiktionslitteratur, der i disse år skrives af forfattere tværs over kloden i et krydsfelt af migration, krige, afkolonialisering og moderniseringsprocesser. Vi skal lære dens effekter at kende i de konflikter og håb, der driver personer og handling i disse forfatteres bøger.

Men vi skal ikke kun læse om globalisering og ikke kun i den nye verdenslitteratur. Larsens pointe er at genlæse litteraturhistorien gennem globaliseringens prisme og se, om de hævdvundne genrer, nationalkanoner og andre rangeringer holder vand, eller om der, og det gør der, dukker nye forbindelsesspor op i den gamle historie set under denne synsvinkel. Det er så det, han gør i bogen, dog ikke bundet af nogen kronologisk orden eller historisk systematik, men mere i en slags kredsende helikopterflyvning hen over det litteraturhistoriske atlas fra Aristoteles og Homer til Jorge Semprun og Bruce Chatwin.

Synspunktet er, at globaliseringen altid har været der, ikke mindst som et element $\mathrm{i}$ litteraturen, hvis temaer har vandret over kontinenterne siden Bhagavad Gita, Moallakat og trubadurerne. Litteraturen har, siger forfatteren, altid "blandet sig dér, hvor nye kulturelle forståelser og betydninger opstår”. Litteraturen er som sådan en privilegeret kunstart og "har altid været model for global tænkning, som gør brydningen mellem lokal erfaring og verden hinsides det lokale konkret”. Hvilket skæres til i bogens stærkeste tese: "Litteratur er selvstændig global tænkning" (8) Dette litterære credo skal jeg vende tilbage til.

Der er mange sigtelinjer i det globale prisme, Larsen syner litteraturen igennem. 
Et par af dem udgår fra den tyske sociolog Ulrich Beck og hans syn på globaliseringen som udfordring til det, han kalder de kulturelle erfaringsmønstre, de kulturelle vidensmodeller og de kulturelle formidlingsformer. Hvilket omsat i Larsens diskussion retter søgelyset mod de mange måder, hvorpå litteraturen agerer i diverse 'åbne' situationer, hvor de sociale, eksistentielle og kulturelle betydninger ikke er lagt fast eller kommer til at rokke ved hinanden. F.eks. i krigen (Jorge Sempruns KZ-transport), i kulturmødet (Karen Blixen i Afrika), i oplysningsprocesserne (Holbergs Erasmus Montanus). Det involverer klassiske filosofiske problemstillinger som sansning over for sprog, oplevelse over for viden, virkelighedsfremstilling, teksthandling og frem for alt ideer i proces, nemlig fordi "litteraturen fremstiller ideer, mens de dannes, men før de er færdige.

"Litteratur beskæftiger sig med den virkelighed, der er for stor til de ideer, vi har, enten de er for mange eller for få.” (140) Det vil sige, at meget af ræsonnementet er spændt op på almenbetragtningernes stillads, men næsten altid - som den valgte metode - i dialog med et eksempel fra litteraturen, som former ræsonnementet undervejs. Larsens tale låner energi fra den litteratur, han bruger som demonstrationseksempler, og han bruger selv i udstrakt grad den litterære teknik, når han binder sine pointer og konklusioner op med billeder fra dit og mit hverdagsliv: forholdet mellem 'afspejling' og 'refleksion' illustreres med plastikreflekserne på vores cykelhjul, erkendelsesarbejdet er, som når vi rydder op i legetøjet efter vores børn. Der er en vis amerikansk campustone i denne form for pragmatisk filosofisk konversation. Meget ofte fungerer retorikken konkluderende, sådan er litteraturen, sådan gør litteraturen. Og det er mestendels positivt, hvad litteraturen er og kan. Larsen har som en anden oplysningsskribent (Holberg er en af hans stjerner, Aristoteles en anden) en optimistisk tro på litteraturens grænseudvidende ressourcer i fremskridtets tjeneste. Som f.eks. når han siger, at den (litteraturen) "gør erindring til en fremstillingsform, der skaber en fremadrettet identitet og nyorienterer fælles lokale traditioner med globalt perspektiv.” (198)

Det moralske engagement er drivkraft i diskussionen hele vejen igennem. Verden kan blive et bedre sted, når fordomme, chauvinisme, selvtilstrækkelighed falder eller bearbejdes i den litterære konversation over grænser. Litteraturen er en helbredende kur, litteraturen har en god sag, og det kan være trøstende for enhver litteraturarbejder, der i svage øjeblikke kan komme i tvivl om, hvorvidt hendes arbejde nu er med til 'at gøre en forskel'. Men det slog mig også undervejs, mens jeg læste, at hele den politiske appel og den globale retoriks indsats for 'kulturmøde', 'grænseoverskridelse', 'åbne definitioner' etc. måske også er en talefigur eller i hvert fald rummer en klangbund for et meget mere gammelkendt vestligt eksistensmotiv, nemlig det rastløse individs søgen efter autenticitet i sit opgør med omverdenens stækkende konventioner og normer. Denne søgende helt kender vi dybt nede i vores europæiske gener, nemlig som ærkeeuropæeren fra 1700- og 1800-tallets oplysning, Sturm und Drang og romantik. Mens i øvrigt en tilsvarende søgen efter 'grænseoverskridelse' i det samme tidsrum var helt ude af billedet øst for Europas grænser. Hvilket ikke er en kritik, blot en tanke. 
Men jeg fremhæver det med et underliggende eksistentielt motiv, så meget mere som nogle af de analyser, der efter min mening står stærkest i bogen, ikke eksplicit handler om kulturmødets konflikter. Således er den store analyse af Gustav Mahlers sangværk Das Lied von der Erde med dens udfletning af de lån og oversættelser af kinesisk poesi, der indgår i værkets helhedsstruktur, fantastisk spændende. Også selv om det, tværs over grænser og med fornyelse af traditionen, handler om så passive og eksistentielle og europæisk fin-de-siècle-agtige stemningskvaliteter som skønhedsrus, melankoli og resignation.

Som sagt, kan man kun føle sig oprustet af at læse i Tekster uden grænser, også selv om man måske selv abonnerer på en anden og mere tempereret holdning med en lurende tvivl på, om litteraturen, den nye og den klassiske fiktionslitteratur, virkelig ejer dette dynamiske potentiale til at gribe formende ind i den globale udvikling. Andre diskussioner andetsteds leverer et andet billede. Nemlig billedet af, hvordan litteraturen er under pres netop i disse årtier og mister publikum i konkurrencen med de andre fremstormende medier, ikke mindst til filmen, som efter alt at dømme nok er lige så potent med hensyn til at udfylde de ufærdige kulturelle definitioner, som hos Larsen suverænt tilskrives litteraturen.

Der er altså flere observanser ude at gå, og der gives divergerende evalueringer af litteraturens status i globaliseringens tidsalder. De kulturkonservative har i et længere stykke tid været fremme på scenen med deres nationale kulturkanoner og deres hægen om habitat og traditionens værdier. Tekster uden grcnser er et velrettet og tiltrængt skub i den modsatte retning. Svend Erik Larsen har taget situationen i øjesyn fra sin optimistiske helikopterhøjde og har aftegnet forbindelseslinjer og knudepunkter på det litterære verdenskort. Andre kan følge op og gå i dybden med udgravninger til de vejanlæg og tunnelbaner, der skal give publikum adgang til de markerede områder.

Marie-Louise Svane er lektor ved Institut for Kunst- og Kulturvidenskab, Københavns Universitet 